\title{
A survey of cellular reactions to environmental stress and disease in Caribbean scleractinian corals
}

\author{
Esther C. Peters \\ Graduate School of Oceanography, University of Rhode Island; \\ Narragansett, Rhode Island 02882-1197, USA
}

\begin{abstract}
Despite growing concern about the demise of coral reefs in many areas of the world, few studies have investigated the possibility that bacteria- or virus-caused diseases may be important agents in the disappearance of living coral tissue from reefs, and that their occurrence and transmission may be influenced by natural or man-made changes in water quality, particularly increased sedimentation and turbidity. One forereef site off St. Croix, U. S. Virgin Islands, and three shallow-water reef sites off Puerto Rico were examined for variations in coral composition, local environmental conditions, and the presence of possible diseases in the stony corals. Visual observations were supplemented with standard histopathological examination under the light microscope of tissues from 257 specimens (representing 9 genera and 13 species), along with additional samples obtained from the Netherlands Antilles, the Grenadines, the Florida Keys and the Smithsonian Coral Reef Microcosm. This procedure proved to be necessary to accurately determine the condition of the colony, to detect the presence of microorganisms, and to correlate tissue health and microparasite infestations with apparent symptoms. These lesions varied with the species and the site. For example, off Guayanilla Bay, three species showed increased or decreased mucosecretory cell development, and another exhibited an unusual microparasite, which may be related to the chronic sedimentation at this site. Although colonies of several species showed signs of "white band disease" at five locations, bacterial colonies composed of Gram-negative rods were present only in acroporid tissues from the relatively pristine St. Croix site and the Netherlands Antilles. The distribution and possible mode of occurrence of these and other diseases and microparasite infestations suggest that acute changes in microhabitat conditions or injuries to individual colonies may be as important to the development of some of these lesions as are chronic adverse environmental conditions over a particular reef.
\end{abstract}

\section{INTRODUCTION}

While accumulating evidence indicates that diseases caused by viruses, bacteria and other microparasites are increasing in many marine invertebrates in environmentally stressed areas (Hodgins et al. 1977; Bang, 1980; Sindermann et al., 1980), few studies have investigated the possibility that such diseases may also be important agents in the disappearance of living coral tissue from tropical shallow-water reefs. Widespread interest in the causes of coral mortalities has only recently developed, notably at the Coral Reef Pathology Workshop held at the Third International Coral Reef Symposium, Miami, Florida (May 1977). Corals have evolved under relatively stable and uniform environmental conditions and are very sensitive to natural or man-made physical and chemical changes in water conditions (Johannes, 1975; Sheppard, 1982). Factors which adversely affect the health of the corals will also affect the condition of the other reef 
dwellers, because of the interactions occurring within this complex ecosystem (Odum \& Odum, 1955; Goreau et al., 1979).

Mortalities of reef corals have been linked to the decrease in water quality due to increased sedimentation and turbidity with continuing resuspension and transport of sediment. These problems are the result of poor management practices in land clearing, discharge of wastes, dredging and filling of coastal margins, and mining of corals for construction, in the Bahamas, the Florida Keys, Puerto Rico, Samoa, Hawaii, Malaysia, Micronesia, the Seychelles and other locations (Stephenson et al., 1958; Goreau, 1964; Johannes, 1972, 1975, 1976; Voss, 1973; Marszalek, 1981; Ricard, 1981). The presence of suspended sediments may stress reef corals by reducing incident light levels essential for the symbiotic zooxanthellae (Muscatine, 1973; Rogers, 1979). Corals also expend energy operating their epidermal muco-ciliary system to remove sediments and prevent physical abrasion or burial (Hubbard \& Pocock, 1972; Schumacher, 1979). Studies by Dodge \& Vaisnys (1977), Bak (1978), Sheppard (1980), and Grigg \& Dollar (1981) suggest that corals may be more tolerant of short-term sediment loading (providing muco-ciliary action can remove the particles), than of chronic high turbidity, in which reduced light levels and the need for constant sediment removal may exceed the coral's counteractive capacity (Stebbing, 1981) and lead to decreased calcification rates, reduced tissue energy replenishment by the zooxanthellae, or death (Squires, 1962; Dodge et al., 1974; Hudson, 1981a). Sedimentation tolerance also varies with the species (Marshall \& Orr, 1931; Roy \& Smith, 1971; Loya, 1972, 1976; Bak \& Elgershuizen, 1976). However, recent observations suggest that adverse water conditions (due to sedimentation or pollutants) may also increase the surface layer of naturally occurring bacteria. These bacteria utilize coral mucus as an energy source, and can cause coral mortalities from bacterial toxins or anoxia (Mitchell \& Chet, 1975; Garrett \& Ducklow, 1975; Peters, 1978; Rublee et al., 1980).

Studies by Antonius (1977) and Dustan (1977) have suggested that the presence of "black line disease" (BLD), "shut-down-reaction" (SDR), and "plague" (characteristics like "white band disease" - WBD), in which coral tissues are sloughed off the skeleton within hours to days, might be associated with chronic increased sedimentation and temperature extremes on Florida Keys reefs. Despite recent field and laboratory observations on BLD (Antonius, 1973; Garrett \& Ducklow, 1975; Ducklow \& Mitchell, 1979), WBD (Gladfelter et al., 1977; Gladfelter, 1982), and SDR (Antonius, 1977), histopathological techniques at the light microscope level have been underutilized in examining the effects of physical injuries, environmental stresses, and the role of microorganisms, in the survival of the stony corals (Rinkevich \& Loya, 1977, 1979; Schumacher, 1979; Peters et al., 1981). Histopathology has become an increasingly important tool for investigating the sublethal effects of environmental perturbations and diseases in marine organisms, and is useful in correlating physicochemical and physiological changes with those changes seen at the population and community level (Yevich \& Barszcz, 1983).

The objectives of this study were twofold: (1) to survey four Caribbean reefs in order to determine the effect of increased sedimentation and turbidity on coral health and the incidence of these diseases, and (2) to use histopathological techniques to examine corals for the presence of microorganisms which might be associated with diseases or other abnormal conditions, and to determine their effects on the coral tissues (Table 1). 
Table 1. Abbreviations for diseases, abnormal tissue conditions, and parasitic infestations of scleractinian corals

\begin{tabular}{|c|c|c|}
\hline Disease or condition & Abbreviation & Citation \\
\hline $\begin{array}{l}\text { "Black line disease" } \\
\text { (="black band disease") } \\
\text { bacteria and cyanobacteria }\end{array}$ & $\mathrm{BLD}(=\mathrm{BBD})$ & $\begin{array}{l}\text { Antonius (1973) } \\
\text { Garrett \& Ducklow (1975) } \\
\text { Mitchell \& Chet (1975) } \\
\text { Ducklow \& Mitchell (1979) } \\
\text { Antonius (1981a) } \\
\text { Antonius (1981b) } \\
\text { This paper }\end{array}$ \\
\hline $\begin{array}{l}\text { "White band disease" } \\
\text { Gram-negative } \\
\text { colonial bacteria }\end{array}$ & WBD & $\begin{array}{l}\text { Gladfelter et al. (1977) } \\
\text { Peters et al. (1983) } \\
\text { This paper }\end{array}$ \\
\hline $\begin{array}{l}\text { Similar "white band disease" } \\
\text { ovoid basophilic bodies similar to those found } \\
\text { in WBD }\end{array}$ & SWBD & This paper \\
\hline Beggiatoa and other bacteria - net formation & $\mathrm{BN}$ & $\begin{array}{l}\text { Mitchell \& Chet (1975) } \\
\text { Ducklow \& Mitchell (1979) } \\
\text { This paper }\end{array}$ \\
\hline "Shut-down-reaction" & SDR & $\begin{array}{l}\text { Antonius (1977) } \\
\text { Antonius (1981a) }\end{array}$ \\
\hline "Stress-related-necrosis" & SRN & $\begin{array}{l}\text { Dustan }(1977) ? \\
\text { Antonius }(1981 b) ? \\
\text { This paper }\end{array}$ \\
\hline $\begin{array}{l}\text { Epidermal cell hyperplasia associated with } \\
\text { chronic physical irritation }\end{array}$ & $\mathrm{ECH}$ & This paper \\
\hline $\begin{array}{l}\text { Tissue changes and necrosis associated with } \\
\text { sedimentation and algal interactions }\end{array}$ & ASN & This paper \\
\hline Nematopsis sp. spores & NS & This paper \\
\hline Coccidean spores & $\mathrm{CS}$ & This paper \\
\hline Unidentified microparasites (ciliates and amoebae) & UMP & This paper \\
\hline Coral neoplasia & NPL & $\begin{array}{l}\text { Lauckner }(1980) \text { - review } \\
\text { Bak (1983) } \\
\text { This paper }\end{array}$ \\
\hline
\end{tabular}

\section{MATERIALS AND METHODS}

\section{Reef locations}

The reefs were first examined in late July 1980 and were revisited in early August 1981. At Tague Bay, St. Croix $\left(17^{\circ} 45^{\prime} 48^{\prime \prime} \mathrm{N}, 64^{\circ} 36^{\prime} 24^{\prime \prime} \mathrm{W}\right)$, most observations were made on the forereef, seaward and east of the reef crest "Swim Channel" (Fig. 1) in depths of $2-8 \mathrm{~m}$. The Tague Bay reef is considered relatively pristine, without sediment or pollutant inputs, except during severe tropical storms (Rogers et al., 1982). However, many divers visit the reef each year (C. S. Rogers, pers. comm.). Off Puerto Rico, site 1 


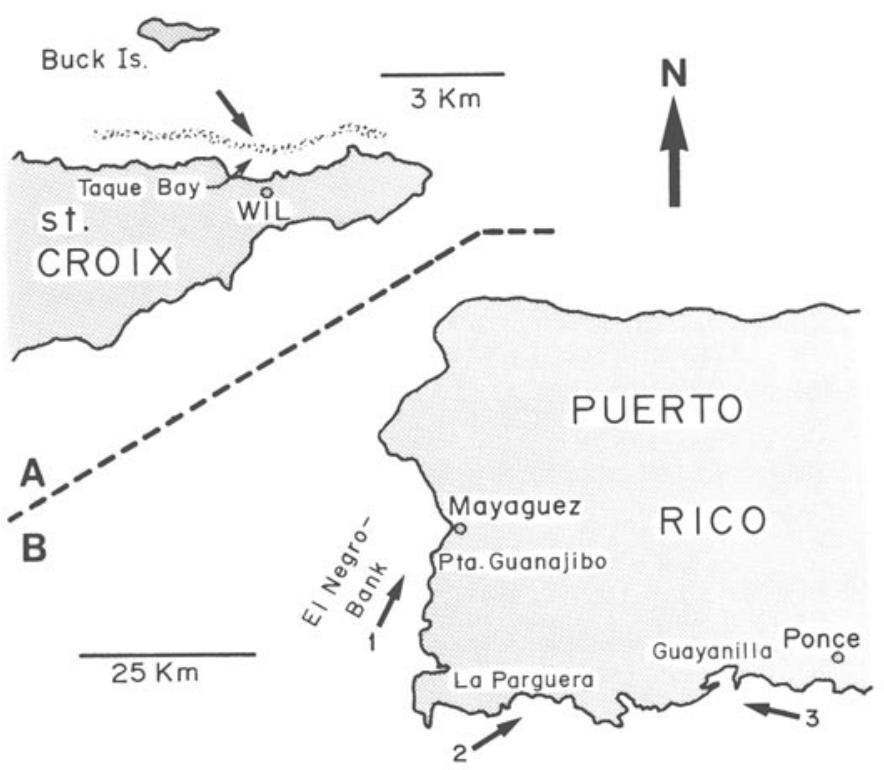

Fig. 1. Sampling sites. (A) Forereef off Tague Bay, St. Croix. (B) Reefs off Puerto Rico: site 1, El Negro-Bank Reef, $6 \mathrm{~km}$ west of Punta Guanajibo; site 2, La Parguera, patch reef northwest end of La Media Luna Reef; site 3, forereef west end of Cayo Maria Langa off Guayanilla Bay

was a shallow patch reef on the El Negro-Bank reefs located approximately $6 \mathrm{~km}$ west of Punta Guanajibo, south of Mayaguez $\left(18^{\circ} 08^{\prime} 18^{\prime \prime} \mathrm{N}, 67^{\circ} 14^{\prime} 36^{\prime \prime} \mathrm{W}\right)$. This area has been little studied, and lacks the extensive reefs found at La Parguera, possibly as a result of river inputs, which may lower salinity and increase turbidity during the rainy season (Loya, 1976; R. J. Zimmerman, pers. comm.). Site 2, at La Parguera, was a patch reef at the northwest end of La Media Luna reef, on the landward side of Cayo Media Luna $\left(17^{\circ} 56^{\prime} 24^{\prime \prime} \mathrm{N}, 67^{\circ} 03^{\prime} 06^{\prime \prime} \mathrm{W}\right)$. The reefs at La Parguera are the most well-developed reefs around Puerto Rico and have been extensively studied (Almy \& Carrion-Torres, 1963; Glynn et al., 1964; Morelock et al., 1977; Rogers, 1977). High summer winds and seas prevented examination of the seaward reefs here. Site 3 was located at the western end of Cayo Maria Langa, a reef at the southern seaward entrance to Guayanilla and Tallaboa Bays $\left(17^{\circ} 58^{\prime} 00^{\prime \prime} \mathrm{N}, 66^{\circ} 45^{\prime} 28^{\prime \prime} \mathrm{W}\right)$. This coastal area has been chronically stressed over the last two decades, receiving chemical and thermal effluents from several industries, an oil refinery, and a steam generating plant, and experiences increased turbidity and sedimentation from shipping traffic (Lopez, 1979). Water depths at the Puerto Rico sites averaged 2 to $3 \mathrm{~m}$. Underwater visibility exceeded $15 \mathrm{~m}$ at the Tague Bay and El Negro sites. Sediments stirred up by summer winds reduced visibility to $9 \mathrm{~m}$ at La Parguera. Underwater visibility at the Guayanilla Bay reef was at most $3 \mathrm{~m}$.

\section{Field observations}

At each site, a general survey of the coral composition of the reef was performed by divers during August 1981 with the aid of five $10 \mathrm{~m}$ transects at intervals of $2 \mathrm{~m}$ parallel 
to the reef crest. Each colony underlying the weighted nylon line was identified to species and the portion of the colony underlying the line was measured to the nearest $\mathrm{cm}$ for a coverage analysis (Loya, 1972, 1977). The condition of each colony was noted. Healthy colonies were considered to be those having a uniform covering of evenly pigmented tissue over a skeletal morphology appropriate for the species, lacking scrapes or other lesions. Photographs were taken of the reefs, and of healthy and diseased corals.

\section{Histopathology}

Small whole colonies or portions of colonies (both apparently healthy and diseased) were removed from the reef with a masonry hammer and chisel, placed in numbered plastic bags with holes cut in them to drain sediment, and collected in a bucket before removing them from the water. Upon returning to shore, colonies were fixed in Helly's solution for $20 \mathrm{~h}$ and rinsed in several changes of freshwater for $24 \mathrm{~h}$ (Barszcz \& Yevich, 1975). Samples were then packed in plastic bags containing diapers soaked in $70 \%$ ethanol for preservation, and shipped to the University of Rhode Island. Subsamples for examination with electron microscopy techniques were removed by chisel from samples taken back to the laboratory, and fixed with a cold glutaraldehyde/formaldehyde solution (Peters et al., 1983).

Photographs were made of each colony using a Zeiss Tessovar low power magnifying camera to record the condition of each coral before decalcification. Tissues were washed in running water for $24 \mathrm{~h}$, and trimmed for processing by standard techniques (Yevich \& Barszcz, 1982). After embedding tissues in Paraplast (Sherwood Medical), $6 \mu \mathrm{m}$ sections of oral, aboral and longitudinal polyp surfaces were cut. Slides were stained with Harris' hematoxylin and eosin ( $\mathrm{H} \& \mathrm{E}$ ), and Heidenhain's aniline blue method ( $\mathrm{HAB}$ ) for connective tissue. Additional stains used on some sections included modified Movat's Pentachrome, Periodic Acid Schiff (PAS)-alcian blue and PAS-alcian blue-hematoxylin, Fuelgen-picroaniline blue, Taylor's modification of Brown \& Brenn's stain for Gram-positive and Gram-negative bacteria, Hirano-Zimmerman method (silver stain), and Grocott's method for fungi (Luna, 1968; C. A. Farley, pers. comm.). Photomicrographs were taken with a Zeiss Photomicroscope III. Samples for electron microscopy were treated and examined as described in Peters et al. (1983). Other colonies of healthy and suspected diseased corals were contributed for diagnosis by these methods from Rincon and Desecheo Islands, Puerto Rico, by V. P. Vicente; from Sandy Island, Grenadines, West Indies, by M. Goodwin, from reefs off Bonaire and Klein Bonaire, by $T$. van't Hof; from Grecian Rocks, Key Largo Marine Sanctuary, Florida, by J. Halas; and from the Coral Reef Microcosm at the Smithsonian Institution, Washington, D. C., by W. Adey and J. Johnson.

Adverse changes in water conditions were reported only at the Microcosm, including sediment resuspension and high nutrient levels (Adey, 1983). The Key Largo reefs have experienced gradually increasing sedimentation in recent years as well as temperature extremes (Dustan, 1977; Hudson, 1981a, b). 


\section{RESULTS}

\section{Reef observations}

The four sampling sites are pictorially compared in Figure $2 \mathrm{~A}-\mathrm{D}$, and the results of the transect surveys for each reef are reported in Tables 2 and 3 . Percent cover of coral colonies was highest at El Negro-Bank reef $(26.28 \%)$, while the Tague Bay forereef had a greater number of species and colonies per transect. The Tague Bay and La Parguera sites were most similar in number of species per transect and area coverage. All of these statistics were significantly lower at the Guayanilla Bay site. The most common coral occurring on all reefs was Porites astreoides, followed by Agaricia agaricites, Montastrea annularis, Favia fragum, and Stephanocoenia michelinii.

The most noteworthy damage to corals was found on colonies of Acropora palmata on both the Tague Bay and El Negro reefs. At Tague Bay, many colonies had been toppled during Hurricanes Frederic and David of 1979 to form a rubble zone (C. S. Rogers, pers. comm.; Rogers et al., 1982), but others remained upright and appeared healthy. Regrowth of damaged colonies was also evident. Of the living colonies, approximately $20-50 \%$ of the branches exhibited signs of WBD, suggesting a major epidemic was underway. In addition, colonies of Acropora cervicornis at the base of the forereef, and one colony of Agaricia agaricites had tissue sloughing off the skeleton. Two cases of BLD were also found on widely separated specimens of Colpophyllia natans (seen in 1980) and Montastrea annularis (seen in 1981). However, in 1981, the disease line was present in 10 colonies of Diploria strigosa within a $2 \mathrm{~m}$ radius at the reef crest swim channel.

No WBD was observed on any colonies of $A$. palmata at El Negro in 1980, but tissues were sloughing off the base of branches of a few small colonies in 1981. Also, in 1981, there was evidence that most shallow colonies of $A$. palmata had died, but patches of live tissue were rapidly overgrowing the algal-covered skeletons. Deeper $A$. palmata were not affected. Although BLD was present on three widely separated colonies of $D$. strigosa and $M$. annularis in 1980, no examples were found in 1981. The general survey of the La Parguera patch reef did not reveal any BLD, but one colony each of $A$. cervicornis and Diploria labyrinthiformes were sloughing tissue off their skeletons in 1981.

A number of colonies on these three reefs were heavily infested with algal mats or lawns, developed by territorial damselfish (principally Eupomacentrus dorsopunicans). Colonies of Montastrea annularis, particularly the knobby variety, were most often affected, as well as Porites porites and Stephanocoenia michelinii (Fig. 2 E-F). Algal "tumors" were observed infrequently on Acropora palmata colonies. These "tumors" consisted of knobs of coral tissue and skeleton growing around a core of filamentous algae, and were also caused by damselfish.

At each of the four reefs examined, coral tissue on many mound-type colonies of various species, including $M$. annularis, Diploria spp., Siderastrea spp., often appeared dark, with ill-defined polyps at the edge of the colony, next to accumulations of filamentous and calcareous algae and sediment on the eroded skeleton. The type of algal accumulations could be differentiated by the presence of damselfish, appearance of the colony edge zone, and the location of the algal patch. The only other visible signs of coral distress were the appearance of patches of whitish filaments, composed of bacteria (Beggiatoa), on the surface of two Porites astreoides colonies, one at the El Negro site 

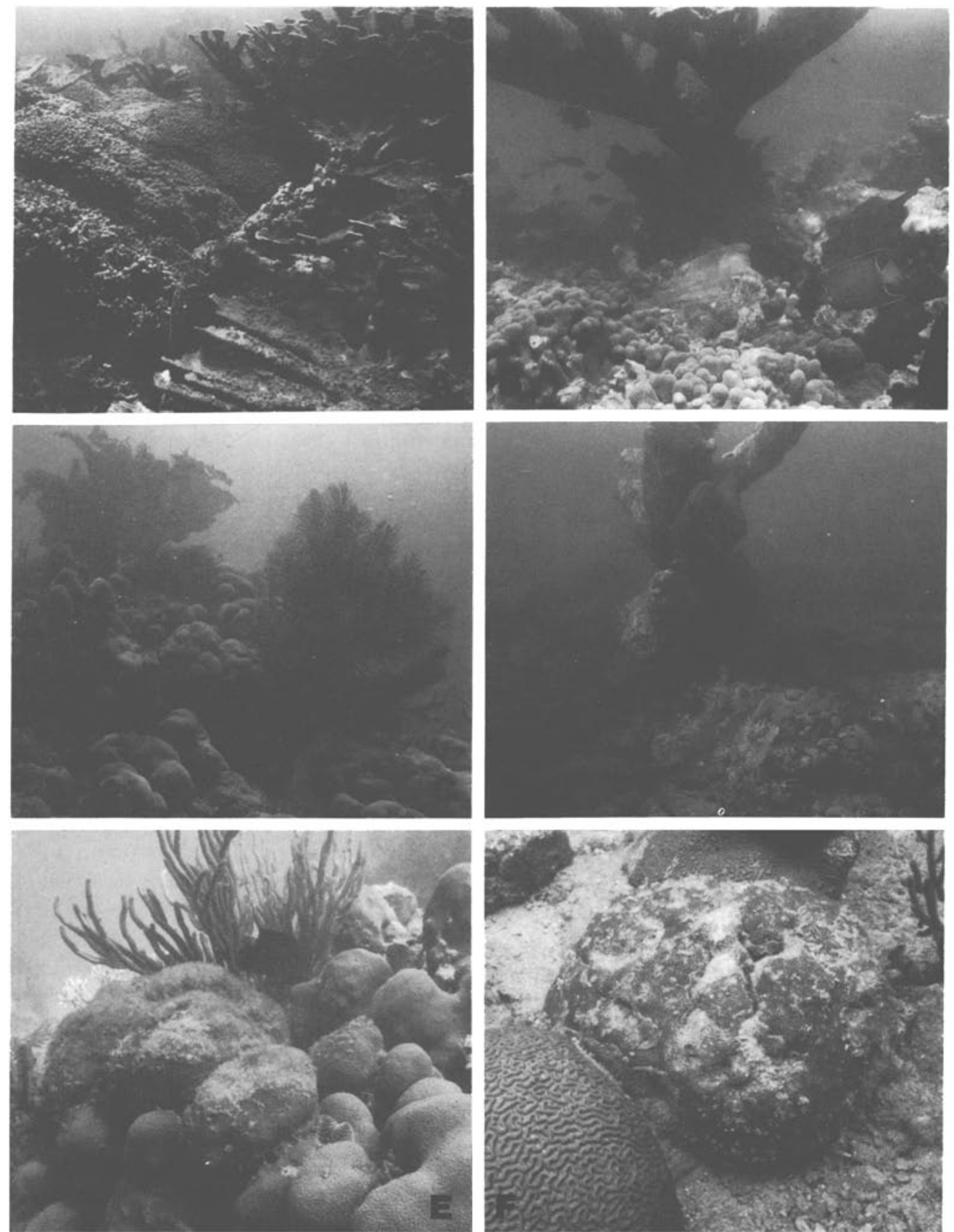

Fig. 2. Reef conditions at the sampling sites. (A) Tague Bay forereef, St. Croix. (B) El Negro-Bank reef shallows. (C) La Parguera patch reef, coarse sediments resuspended by summer winds. (D) Guayanilla Bay, Cayo Maria Langa reef, note turbidity, erosion of dead corals, and scarcity of living corals. (E) Damselfish with territorial algal lawn on Montastrea annularis colony, La Parguera. (F) Algal tufts on surface on Stephanocoenia michelinii colony, El Negro 
Table 2. Statistics calculated for five transects at each of the three reef sites, Puerto Rico, and the Tague Bay forereef, St. Croix, as average values per transect. Standard deviations in parentheses. $\mathrm{H}_{\mathrm{N}}^{\prime}=$ Shannon-Weaver index of diversity. $\mathrm{H}^{\prime}{ }_{\mathrm{C}} / \mathrm{H}_{\max }^{\prime}=$ Pielou's evenness index, a measure of the degree of dominance in a sample. (After Loya, 1976)

\begin{tabular}{|c|c|c|c|c|c|c|}
\hline Location & $\begin{array}{c}\text { Total No. } \\
\text { species }\end{array}$ & $\begin{array}{c}\text { No. } \\
\text { species }\end{array}$ & $\begin{array}{l}\text { No. } \\
\text { colonies }\end{array}$ & $\begin{array}{c}\text { Cover } \\
\%\end{array}$ & $\mathrm{H}_{\mathrm{N}}^{\prime}$ & $\mathrm{H}_{\mathrm{C}}^{\prime} / \mathrm{H}_{\max }^{\prime}$ \\
\hline Tague Bay & 7 & $\begin{array}{c}5.00 \\
(1.00)\end{array}$ & $\begin{array}{c}18.00 \\
(6.04)\end{array}$ & $\begin{array}{c}13.96 \\
(6.62)\end{array}$ & $\begin{array}{c}1.316 \\
(0.163)\end{array}$ & $\begin{array}{c}0.818 \\
(0.033)\end{array}$ \\
\hline El Negro-Bank Reef & 5 & $\begin{array}{c}3.40 \\
(0.89)\end{array}$ & $\begin{array}{c}15.40 \\
(4.04)\end{array}$ & $\begin{array}{c}26.28 \\
(11.26)\end{array}$ & $\begin{array}{c}0.921 \\
(0.293)\end{array}$ & $\begin{array}{c}0.779 \\
(0.091)\end{array}$ \\
\hline La Parguera & 11 & $\begin{array}{c}4.40 \\
(2.19)\end{array}$ & $\begin{array}{c}8.40 \\
(4.51)\end{array}$ & $\begin{array}{l}10.02 \\
(7.22)\end{array}$ & $\begin{array}{c}1.130 \\
(0.640)\end{array}$ & $\begin{array}{c}0.629 \\
(0.355)\end{array}$ \\
\hline Guayanilla & 4 & $\begin{array}{c}1.60 \\
(0.89)\end{array}$ & $\begin{array}{c}2.20 \\
(1.30)\end{array}$ & $\begin{array}{c}0.90 \\
(0.43)\end{array}$ & $\begin{array}{c}0.347 \\
(0.491)\end{array}$ & $\begin{array}{c}0.354 \\
(0.485)\end{array}$ \\
\hline
\end{tabular}

Table 3. Relative abundance of coral species at the Tague Bay forereef, St. Croix, and the three reef sites, Puerto Rico. Index for relative abundance of corals: average number of colonies per $10 \mathrm{~m}$ transect is between $0.1-1.0=$ rare; $1.1-2.0=$ sporadic $; 2.1-4.0=$ common; $^{4} .1-7.0=$ abundant;

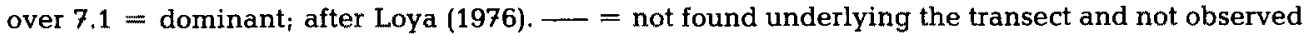

within the total transect area. obs. = observed within the total transect area of the reef site

\begin{tabular}{|lllll|}
\hline \multicolumn{1}{c}{ Species } & Tague Bay & El Negro & La Parguera & Guayanilla \\
\hline Acropora cervicornis & - & - & & - \\
Acropora palmata & rare & abundant & - & rare \\
Agaricia agaricites & dominant & rare & rare & rare \\
Colpophyllia natans & obs. & - & rare & - \\
Dichocoenia stokesii & - & - & obs. & - \\
Diploria labyrinthiformes & - & - & obs. & - \\
Diploria strigosa & - & rare & rare & obs. \\
Eusmillia fastigiata & - & - & rare & - \\
Favia fragum & rare & obs. & rare & obs. \\
Montastrea annularis & obs. & obs. & common & obs. \\
Montastrea cavernosa & - & - & rare & - \\
Porites astreoides & abundant & sporadic & rare & sporadic \\
Porites porites & common & dominant & - & - \\
Siderastrea radians & - & - & rare & rare \\
Siderastrea siderea & rare & obs. & rare & - \\
Stephanocoenia michelinii & rare & obs. & obs. & obs. \\
\hline
\end{tabular}

and one at the Guayanilla site (noted in separate years), and on one colony of Diploria labyrinthiformes from Tague Bay (seen in 1980).

\section{Histological examinations}

This survey revealed several surprises, particularly the presence of microparasites within healthy-appearing, as well as necrotic, coral tissues. 


\section{Reproduction}

Table 4 contains the observations of gonad development, and/or the presence of planula larvae in the colonies examined for each site. Data for both years were combined, with note made of significant differences between years for some of the samples collected. The largest number of samples of Acropora cervicornis and Acropora palmata were collected in 1981 for another study (see below), and revealed that not all colonies from this site developed gonads concurrently. Three colonies of $A$. palmata from El Negro (1981) contained planula larvae and were lacking gonads, while others contained ova and sperm. Colonies of this species collected from the Guayanilla Bay site may have been immature, since these colonies were all small $(<12 \mathrm{~cm}$ high) and all other species collected from this site contained gonads. The colonies of $A$. cervicornis from La Parguera were necrotic. Presence of gonads in both species from Tague Bay did not correlate with WBD symptoms ( 76 and $38 \%$ of diseased $A$. cervicornis and $A$. palmata, respectively, had developing gonads). The data also suggest differences in gonad development and spawning between different species on the four reefs, and between the reefs, especially for Porites astreoides at the Guayanilla Bay site. Differences in the collections from 1980 and 1981 indicate individual variability and effects of seasonal cycles on reproduction.

\section{Coral-algal interactions}

Colonies infested by damselfish algal lawns experienced cellular erosion and tissue necrosis as algae invaded the skeleton (Fig. $3 \mathrm{~A}-\mathrm{B}$ ). Although the degeneration of the tissue may have been initiated by the damselfish, in some cases the algae were in direct contact with calicoblast tissue which exhibited a "blistering" necrosis of the cells (ASN). This ASN was observed in colonies of Diploria strigosa, Sidereastrea siderea, and $S$. radians, as well as in Montastrea annularis, Porites porites, and Stephanocoenia michelinii, from all the reef sites, and in the Grenadines' samples of $M$. annularis, Diploria clivosa, $D$. strigosa, Meandrina meandrites and $S$. siderea. The darkened edge of tissue (Fig. $3 \mathrm{C}$ ) adjacent to sediment-algal accumulations on the skeletons of moundtype colonies of Colpophyllia natans, $D$. strigosa, Favia fragum, $M$. annularis, Porites astreoides, $S$. radians, $S$. siderea, and $S$. michelinii, as well as the branching corals Acropora cervicornis and $P$. porites, had changed from the normal epidermal structure (tall columnar cells uniformly interspersed with mucus-secretory cells) to a hyperplasia (ECH) of the columnar epidermal cells (Fig. 3 D). Various colonies from all four locations were affected by this process. Additionally, elongated algal filaments, with a basophilic wall, containing spherical bodies, were found in the tissues of colonies of Porites spp. and S. radians from El Negro and Guayanilla Bay in 1981 (Fig. 3 E). The coral tissue responded by developing a hyperplasia of columnar cells and fibrocytes in an attempt to wall off these algae.

One unexpected finding was the occurrence of basophilic sheathed structures, which appeared to be associated with the boring green skeletal alga Ostreobium $\mathrm{sp}$. (Fig. 3 F). These modified filaments appear to compress the calicoblast layer of tissue (consisting of the gastrodermal cells, mesogloea, and calicoblast epithelium) and distort the normal structure of the tissues. Filaments can also be seen in cross-section as they invade the gastrodermal cells. These structures were found in colonies of Agaricia 
Esther C. Peters

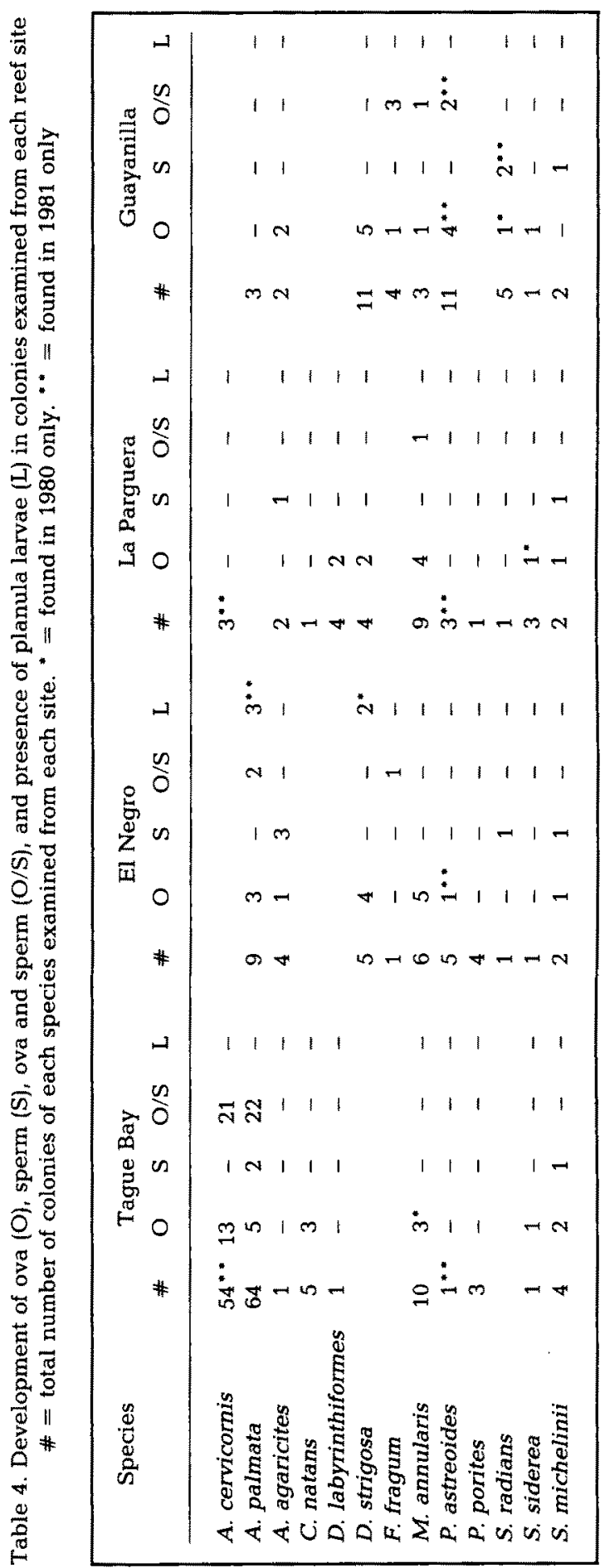


agaricites, Diploria labyrinthiformes, $D$. strigosa and Montastrea annularis from the Puerto Rican reefs only. Lukas (1973) did not believe that these endolithic algae could penetrate the living coral tissue, although she had observed the filaments to extend to the edge of the coral skeleton. Upon viewing these slides, she could not determine the nature of these algal structures (pers. comm.). Additional studies on this phenomenon are now underway.

\section{Bacteria-associated diseases}

The total number of colonies collected for each species is shown in Table 5 along with the number of colonies in which necrosis, tissue changes, and microorganisms were observed in each species and at each location. Colonies of Agaricia agaricites and Diploria strigosa exhibited increased muco-secretory cell development at the Guayanilla reef site (Fig. 4 A-B). Favia fragum from El Negro and Guayanilla showed similar responses of the epidermis, but were more variable. Changes were also seen in coral tissues from the Coral Reef Microcosm (Fig. $4 \mathrm{C}$ ). Three of these colonies possessed abundant active mucosecretory cells, but other samples exhibited loss of mucus cells from the epidermis (Fig. 4 D). Although tissue on all of these colonies had appeared superficially normal at the time of collection (except for sloughing of tissue around the base of each colony or branch), all of the tissues were in varying stages of degeneration and necrosis. This same condition was found in colonies of Agropora palmata, A. cervicornis and Diploria labyrinthiformes collected from La Parguera and El Negro. None of these necrotic corals contained visible microorganisms, and only the specimen of $D$. labyrinthiformes showed developing gonadal tissue.

In contrast, all of the colonies of Acropora palmata and $80 \%$ of the A. cervicornis colonies examined from the Tague Bay reef, including those that appeared healthy without signs of WBD (Fig. 4 E), contained ovoid basophilic bodies up to $40 \mu \mathrm{m}$ or more in diameter, surrounded by a refractile wall (Fig. 4 F). These Gram-negative bodies were found throughout the tissue remaining on the skeleton, scattered in the mesenteries and calicoblast tissue of the gastrovascular canals. Examination of these bodies by electron microscopy revealed that they are composed of rod-shaped bacteria in a colony, surrounded by coral cells (Peters et al., 1983). Microscopic counts of colonies per area of tissue showed that the number of bacterial colonies was significantly higher in diseased corals, although numbers in both obviously diseased and apparently healthy corals overlapped (diseased range $0.1-1.8, \bar{x}=0.62$, versus healthy range $0.0-0.8, \bar{x}=0.37$, $\mathrm{p}<0.005, \mathrm{n}=25$, two sample t-test). There was no correlation between presence or absence of gonads and number of bacterial colonies per unit of tissue. These bacteria were also found in samples of Acropora spp. from Bonaire (with indications of disease), the Grenadines and the Florida Keys. Similar ovoid basophilic bodies were also found in Agaricia agaricites in which tissue was sloughing from the base of the colony, and in one-third of the apparently healthy colonies of $A$. agaricites and Stephanocoenia michelinii, from widely separate locations on the four reefs. Two-thirds of the Porites astreoides examined contained similar ovoid basophilic bodies in the mesogloea of the tentacles. These bodies did not appear to be associated with any necrosis and differed from the WBD-associated bacterial colonies in that the "rods" within the body are larger (Fig. 5 A), crescent-shaped, and break apart from one another very easily in these 

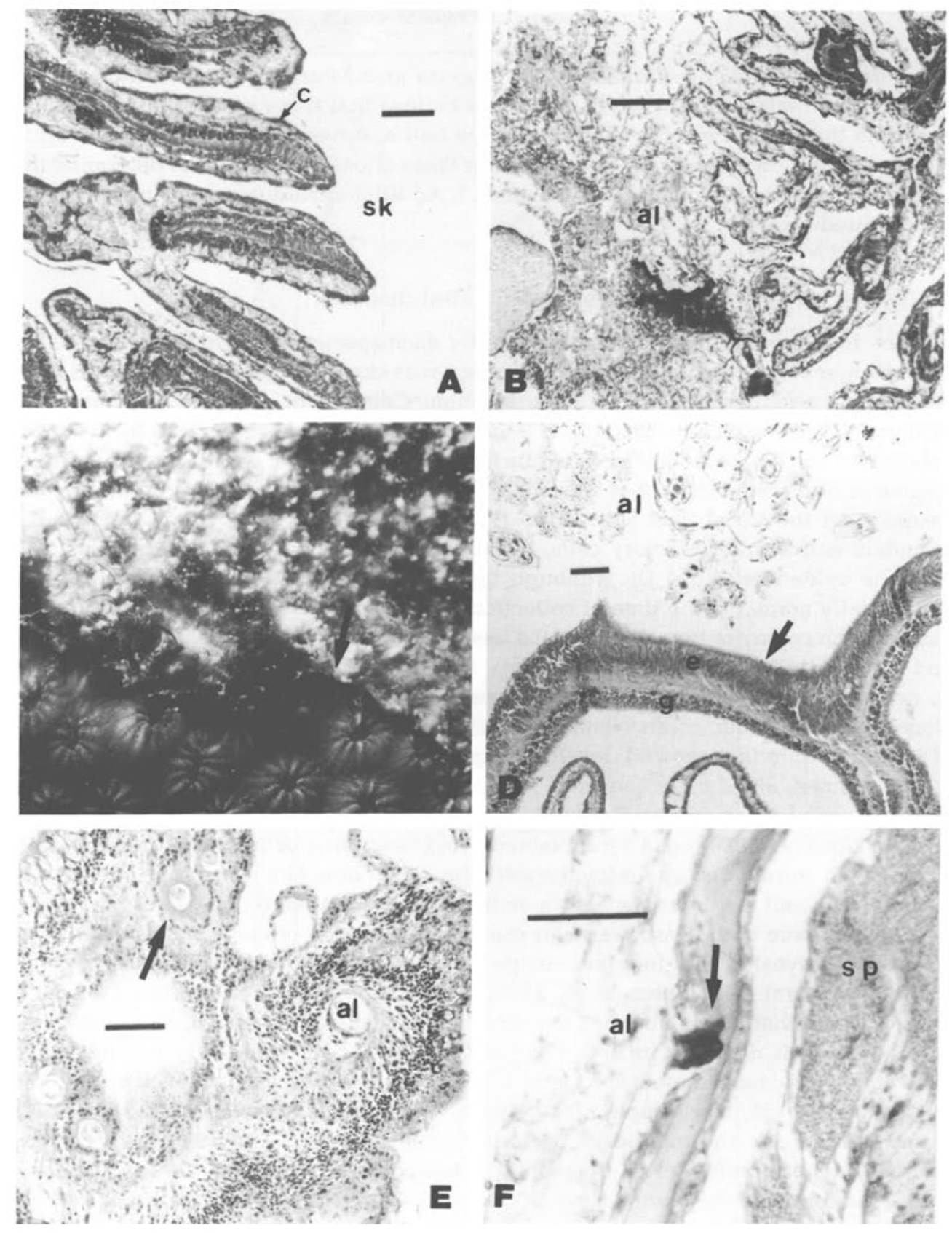

Fig. 3. Coral lesions associated with physical injuries from algae and sedimentation. Scale bars $=$ $50 \mu \mathrm{m}$ (A) Cross-section of portion of healthy polyp of Stephnocoenia michelinii, stained with $\mathrm{H} \& \mathrm{E}$, La Parguera. (B) Cross-section of polyp damaged by algal erosion, H \& E, La Parguera. (C) Gross appearance of sediment-algal border of Montastrea annularis colony, note darkened tissue, Tague Bay. (D) Photomicrograph of epidermal cell hyperplasia next to sediment-algae accumulation, $M$. annularis, H \& E, El Negro. (E) Fibrocytic hyperplasia in tissue of Siderastrea radians chronically irritated by algae, $\mathrm{H} \& \mathrm{E}_{\text {\& }}$ Guayanilla Bay (F) Unidentified endolithic algae-associated structure invading gastrodermis of Diploria strigosa through calicoblastic epithelium, H \& E, Desecheo Island, $\mathrm{al}=$ algae; $\mathrm{c}=$ calicoblastic epithelium; $\mathrm{e}=$ epidermis; $\mathrm{g}=$ gastrodermis; $\mathrm{sk}=$ former position of skeleton; $s p=$ spermary 
Cellular reactions in corals

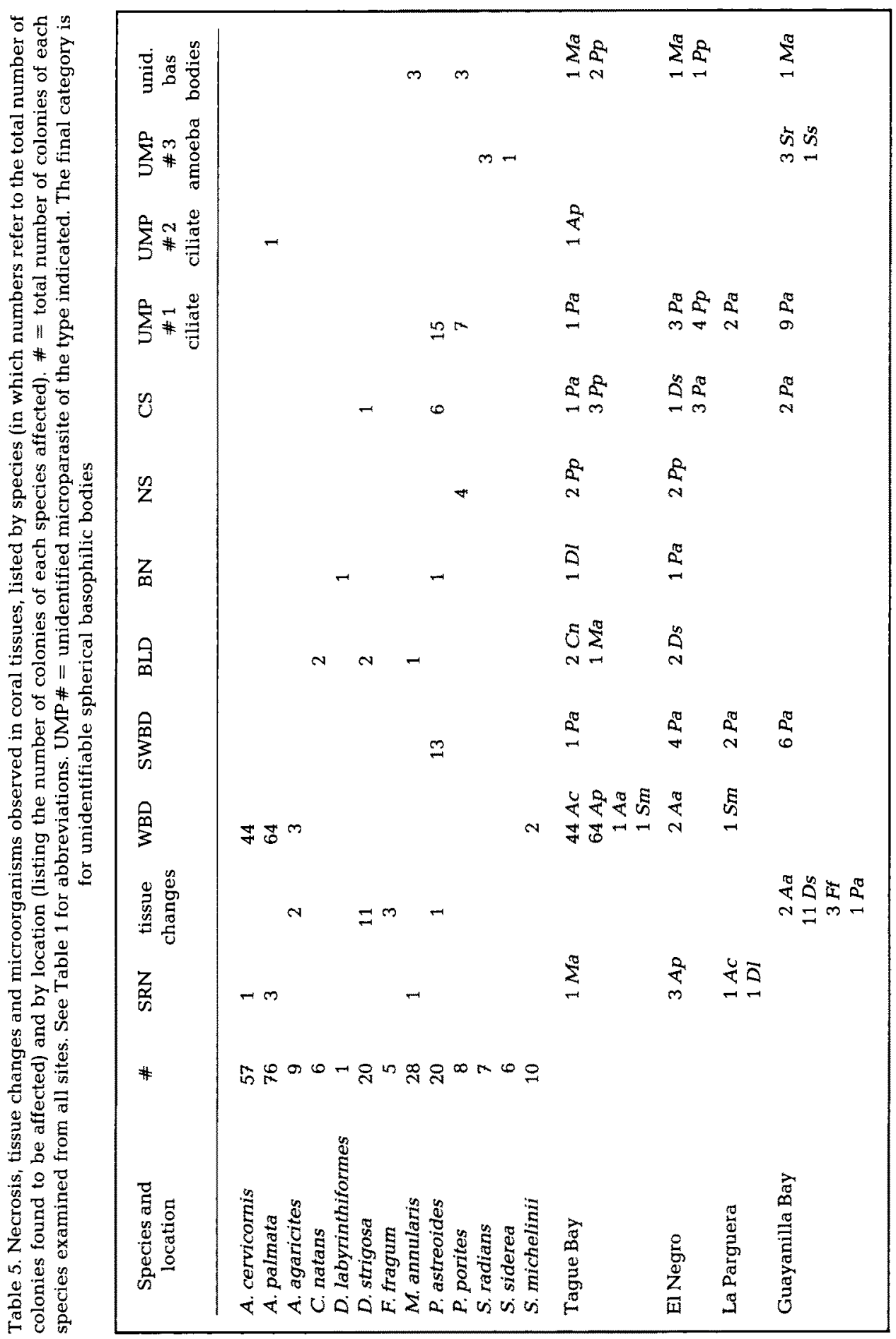



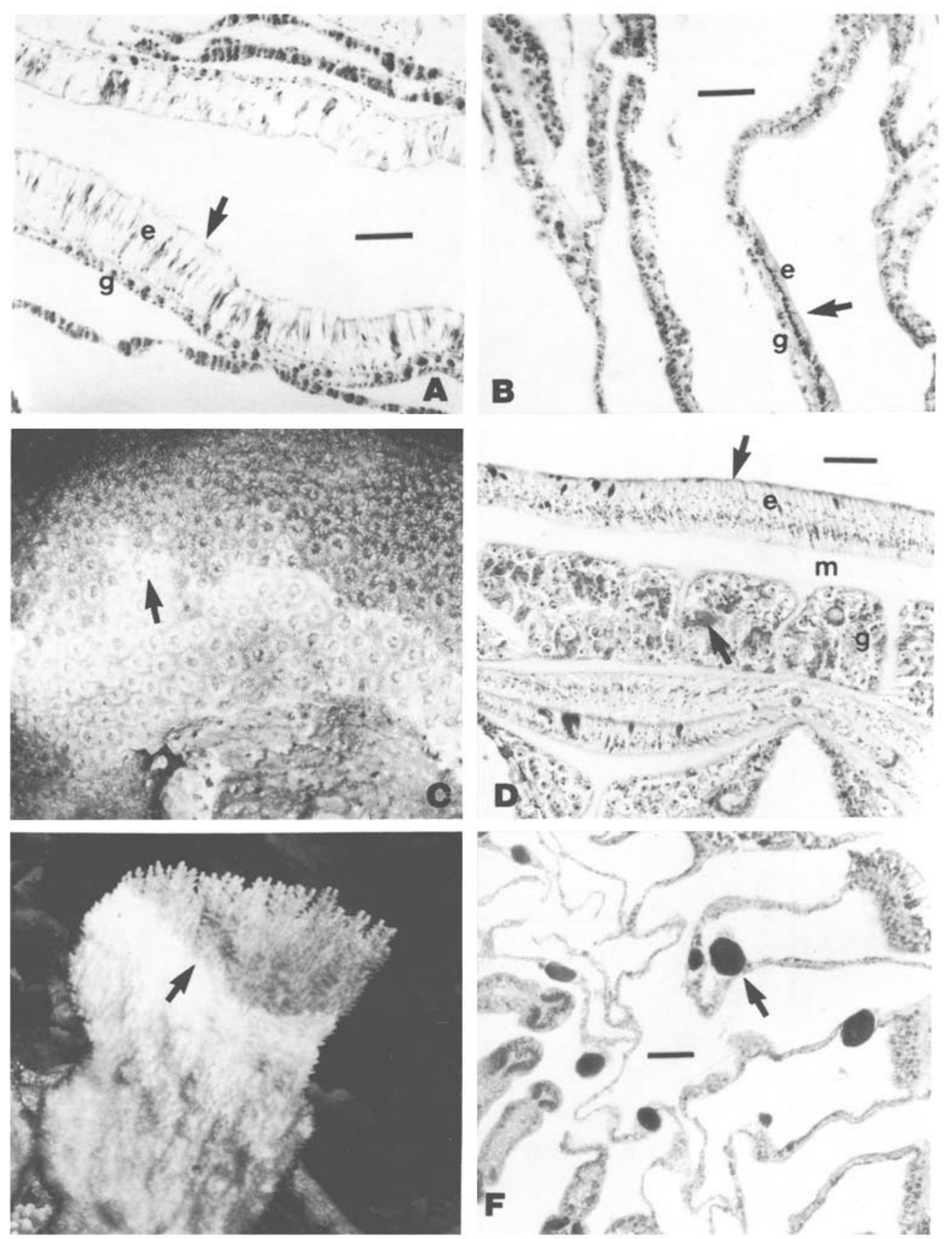

Fig. 4. Tissue changes and necrotic conditions. Scale bars $=50 \mu \mathrm{m}$. (A) Photomicrograph of healthy tissue from Agaricia agaricites, H\& E, El Negro. (B) Epidermal erosion of A. agaricites, H\& E, Guayanilla Bay, (C) Healthy appearing Montastrea annularis with tissue sloughing off the base of the colony, after fixation, Coral Reef Microcosm. (D) Photomicrograph of abnormal tissue from similarly afflicted $M$. cavernosa, $\mathrm{H} \& \mathrm{E}$, Coral Reef Microcosm. (E) Sloughing of tissue from branch of Acropora palmata in "white band disease", Tague Bay. (F) Ovoid Gram-negative bacterial colonies in tissues of diseased A. palmata, $\mathrm{H} \& \mathrm{E}$, Bonaire. $\mathrm{e}=$ epidermis; $\mathrm{g}=$ gastrodermis; $\mathrm{m}=$ 
preparations. They have not yet been examined by electron microscopy to determine their true nature.

Colonies of Colpophyllia natans, Diploria strigosa and Montastrea annularis, from the four reef sites and Key Largo, were collected in order to examine the effects of BLD microorganisms on the coral tissue (Fig. 5 B). Necrosis of tissue occurred only at the disease line, which contained a variety of microorganisms, including ciliates, cyanobacterial filaments, spiral and rod-shaped bacteria (Fig. $5 \mathrm{C}$ ). The remainder of the coral tissue was healthy, with gonads and planula larvae present (Table 3 ). However, the $M$. annularis sample from Tague Bay showed patches of necrotic tissue over the entire surface of the sample.

\section{Other microparasites}

Besides the bacteria, a number of protozoans were found in otherwise apparently healthy coral tissue. Thick-walled ovoid capsules $(14 \mu \mathrm{m} \times 17-20 \mu \mathrm{m})$ were found in the calicoblast epithelium of Porites porites colonies (Fig. $5 \mathrm{D}$ ). One sample of this species from the Coral Reef Microcosm was especially infested. These have tentatively been identified as a sporozoan, Nematopsis sp. (C. A. Farley, pers. comm.). These spore capsules stain intensely red with HAB, lightly with PAS, and not at all by the Fuelgen technique (although this stain may not have worked properly due to decalcification of the coral tissue). These sporozoans appeared to cause an hypertrophy of the calicoblast epithelial cells, with an increase in eosinophilic intracellular granules. They are classified in the family Porosporidae, with a life cycle previously reported to include crustacean and mollusc hosts (Kudo, 1966). Another type of spore was observed in the lobes of the mesenterial filaments in Diploria strigosa and Porites astreoides in $1981 \mathrm{from}$ the Tague Bay, El Negro, and Guayanilla sites (Fig. 5 E), and also found in mesenterial filaments of Montastrea cavernosa and Meandrina meandrites from Rincon, Puerto Rico. These latter spores, $6-7 \mu \mathrm{m} \times 12 \mu \mathrm{m}$, with 3 or more basophilic bodies in each, are Fuelgen positive, and have been tentatively identified as coccidean spores ( $F$. Kern and C. A. Farley, pers. comm.). No other stages of these sporozoan life cycles were observed.

Large ciliates were often found feeding in association with necrotic tissue, but also occasionally found on the surfaces of healthy corals (Fig. $5 \mathrm{~F}$ ). Colonies of Porites astreoides and $P$, porites contained a ciliate (C. A. Farley, pers. commun.), in the gastrodermal cells lining the gastrovascular canals in these species (Fig. $6 \mathrm{~A}$ ). This ciliate exhibits one macronucleus and one or more micronuclei, and is most easily seen with the HAB when the cytoplasm stains light blue. Another ciliate was found in the epidermis of one colony of Acropora palmata from Tague Bay, which was originally collected to look at a scraped lesion on its surface. The entire epidermis of this sample was necrotic and sloughing, with these ciliates embedded in the cell layer (Fig. 6 B). Amoebae were found in the calicoblastic epithelium of both Siderastrea spp. from Guayanilla Bay. The concentration of amoebae obliterated the calicoblast cells (Fig. 6 C). One colony of Colpophyllia natans from the Grenadines contained worm-like organisms (P. Yevich, pers. comm.) embedded in a layer of enlarged necrotic gastrodermal cells (Fig. 6 D). Additionally, spherical basophilic bodies were occasionally observed in the mesenterial filaments of $M$. annularis and $P$. porites colonies from all locations except La Parguera. More recent observations on the ciliates (UMP\#1 and UMP\#2, Figs $6 \mathrm{~A}$ and $6 \mathrm{~B}$ ) indicate that these structures are probably nematocysts in various stages of development (\#1) or degeneration (\#1 and \#2). 

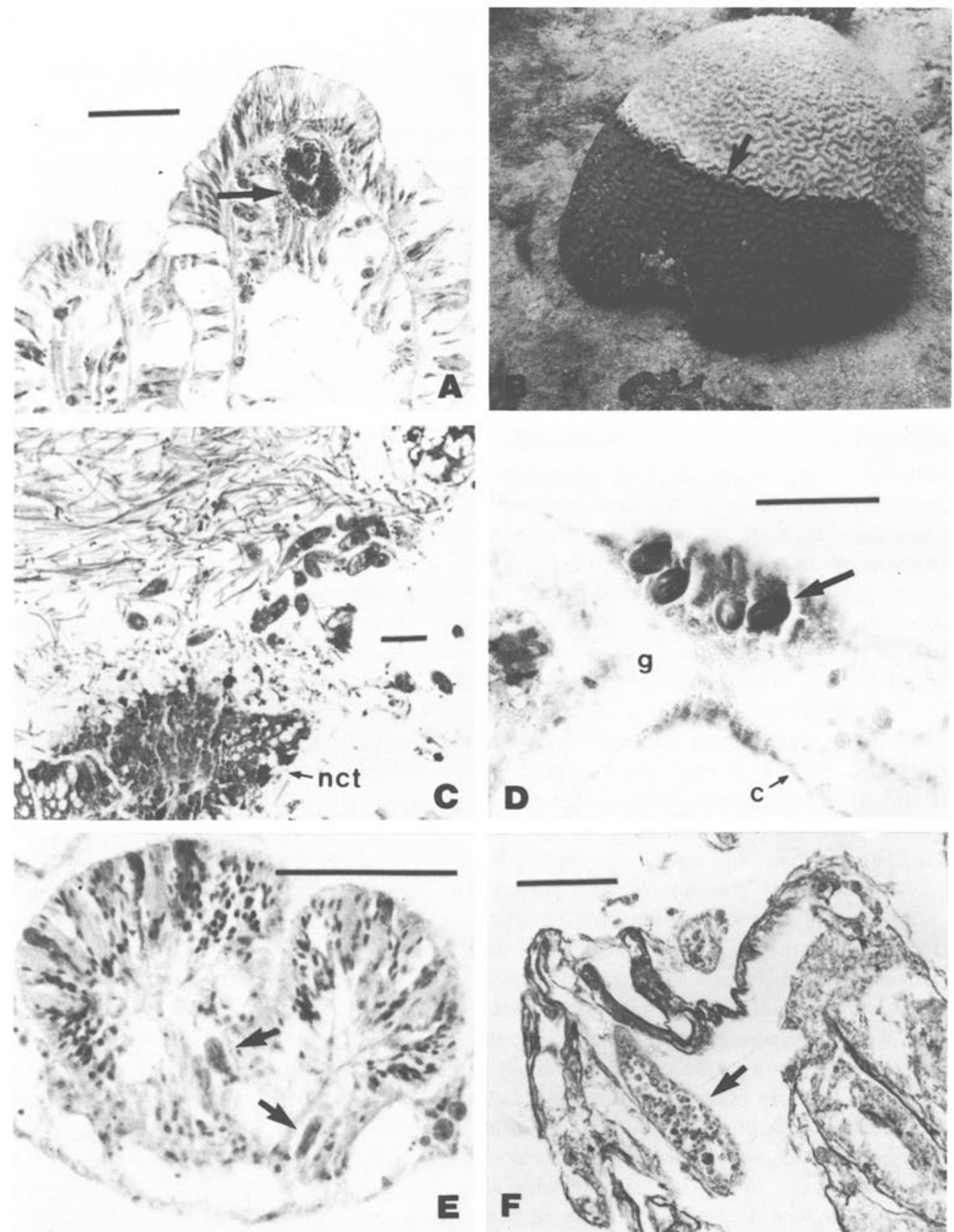

Fig. 5. Coral diseases and microparasites. Scale bars $=50 \mu \mathrm{m}$. (A) Basophilic body similar to that found in "white band disease" coral tissue from colony of Porites astreoides, HAB, La Parguera. (B) "Black line disease" on colony of Diploria strigosa, El Negro. (C) Microorganisms of "black line disease" and necrotic coral tissue, D. strigosa, HAB, El Negro. (D) Nematopsis sp. spores in calicoblastic epithelium of $P$. porites, HAB, El Negro. (E) Unidentified coccidean spores in mesenterial filaments of $P$. astreoides, $\mathrm{H} \& \mathrm{E}_{i}$ El Negro. (F) Ciliates associated with necrotic $D$. strigosa tissue, $H$ \& E, Coral Reef Microcosm. $c=$ calicoblastic epithelium; $g=$ gastrodermis nct $=$ necrotic coral tissue 


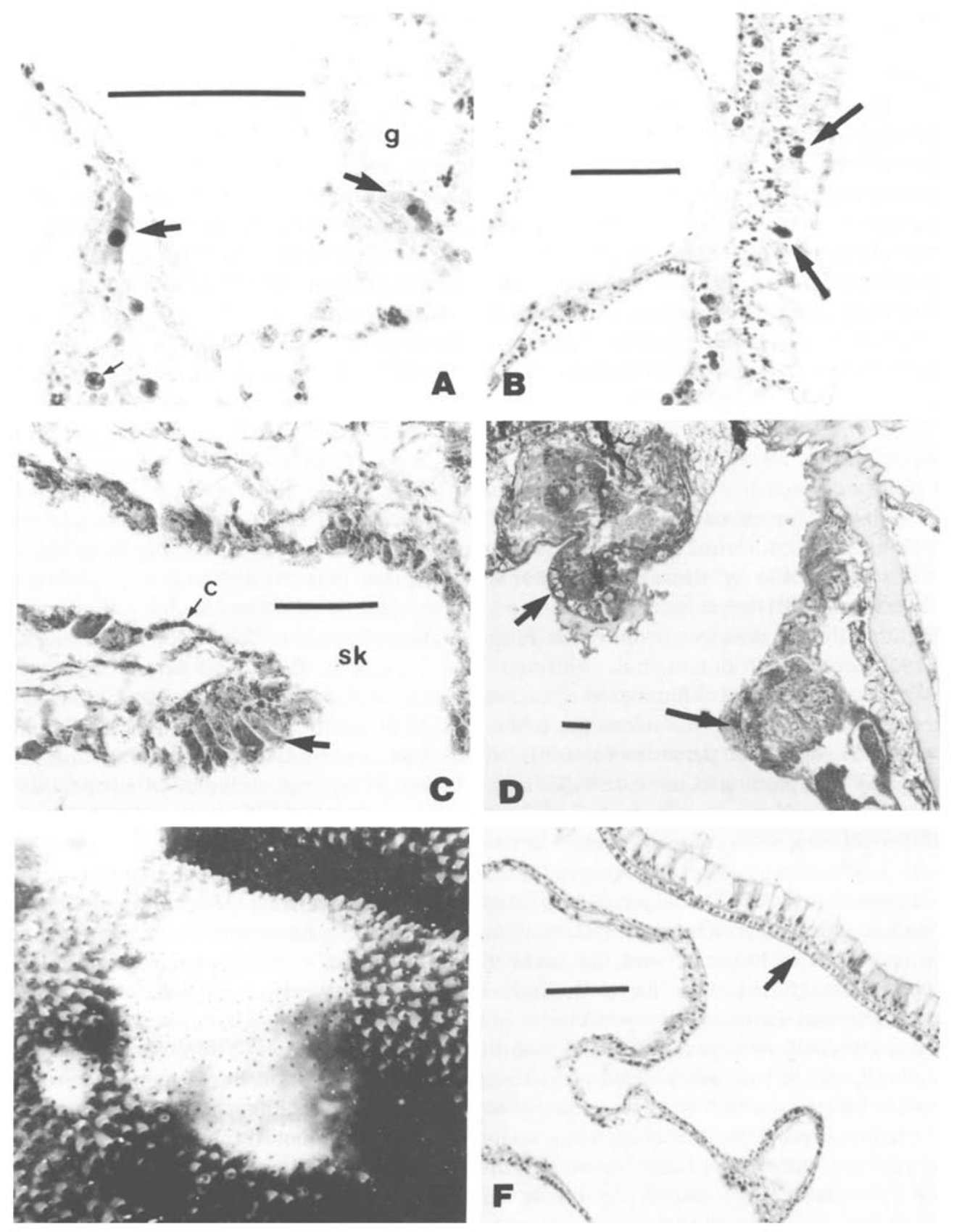

Fig. 6. Additional microparasites of corals, and skeletal abnormalities. Scale bars $=50 \mu \mathrm{m}$. (A) Unidentified ciliate (\#1) in gastrodermal cells of Porites porites, HAB, El Negro. (B) Unidentified ciliate (\#2) destroying epidermis of Acropora palmata, HAB, Tague Bay. (C) Unidentified amoebae (\#3) infesting calicoblastic epithelium of Siderastrea radians, H \& E, Guayanilla Bay. (D) Endoparasitic worm in gastrodermal tissue of Colpophyllia natans, H \& E, Grenadines, (E) Specimen of $A$. palmata with skeletal tumor, Key Largo Marine Sanctuary. (F) Photomicrograph of $A$. palmata tumor tissue. Note lack of zooxanthellae in gastrodermis, and changes in tissues surrounding the gastrovascular canals, HAB, Key Largo. $\mathrm{c}=$ calicoblastic epithelium; $\mathrm{g}=$ gastrodermis; sk $=$ former location of skeleton 


\section{Coral tumors}

Skeletal abnormalities were found in samples of Acropora palmata collected from Grecian Rocks, Key Largo (Fig. 6 E). Histopathological examination of the tissues revealed rapid proliferation of the calicoblast layers of the gastrovascular canals, producing a bulging porous skeleton overgrowing the polyps. Although an epidermal cell layer covers the surface of this area, the cells differ structurally and zooxanthellae are absent from the gastrodermis in all areas of this growth (Fig. $6 \mathrm{~F}$ ). Because of the appearance of uncontrolled growth, destruction of polyps, changes in cell structure and function, and spread of the abnormal skeletal growth along a branch, this condition appears to be a true neoplasia of the coral (Cheney, 1975; Bak, 1983; J. C. Harshbarger, pers. comm.). These tumors will be discussed more fully in a future paper.

\section{DISCUSSION}

Except for an earlier note (Peters et al., 1983), this is the first report of bacterial colonies and protozoal microorganisms living within coral tissues, and the first observations that some of these microorganisms may be harmful to the corals. Although Lauckner (1981) reported no studies on viral or bacterial diseases in the cnidarians, he believed such diseases would be found, especially since Burkholder \& Burkholder (1958) could not demonstrate antimicrobial activity in tissues of Acropora palmata, Porites porites and Montastrea sp. Commensal and parasitic protozoans have been reported from other cnidarians (Lauckner, 1981; T. Jacques, pers. comm.), but the only previous reports of parasites in corals were on damage to tissues of the Pacific Porites spp. by trematode metacercariae (Cheng \& Wong, 1974), and endoparasitic copepods in a number of Indo-Pacific and Caribbean species (Stock, 1975; Butter, 1979; Herriott \& Immerman, 1979; other literature reviewed in Lauckner, 1980).

In a review of coral pathology, Antonius (1981a) suggested that the tissue sloughing observed in WBD was a physiological reaction to some stress. He could not find any microorganisms which might be removing the tissue, the disease could not be spread by inoculation techniques, and the coral did not recover when treated with antibiotics (Antonius, 1981b). The histopathological examinations performed here demonstrated that unusual Gram-negative bacterial colonies were present in Acropora and Agaricia spp. which show signs of WBD. These bacteria were also found in apparently healthy colonies on the same reefs. Whether these bacteria are responsible for this disease has yet to be proven, but, if they are, it is possible that a threshold concentration in colonies is necessary before the tissue begins sloughing. These bacteria may be impervious to traditional antibiotics, or, when the disease finally becomes apparent, the tissue damage is irreversible. This might explain Antonius' observations. Other colonies of Acropora palmata and $A$. cervicormis, as well as colonies of Diploria labyrinthiformes and Montastrea annularis in this study did not have observable microorganisms within their tissues, yet necrosis was evident. Similar sloughing of coral tissues from several species of Microcosm corals revealed degenerative changes in cell morphology and function, which might be related to the high nutrient or sedimentation levels in the tank. Antonius (1981b) also reported tissue sloughing in colonies of Montastrea annularis and Diploria strigosa, and Dustan (1977) observed this in colonies of Mycetophyllia ferox, which they 
correlated with environmental stress. However, the corals were not examined histologically.

I propose the term "Stress-Related-Necrosis" (SRN) to differentiate cases in which corals show signs of WBD and in which degenerative changes in cell structure are observed in the absence of obvious pathogens (as determined by microscopic examination of the fixed and embedded tissues), from WBD, in which ovoid Gram-negative bacterial colonies are found in the coral tissues. However, future studies utilizing electron microscopy or other techniques may find a virus or bacteria associated with this disorder. Dustan (1977) reported successful inoculations of apparently healthy colonies of Mycetophyllia ferox, M. larmarkiana and Colpophyllia natans with tissue from "plague"-infected colonies of $M$. ferox and $C$. natans, suggesting species-specific differences in resistance, or perhaps different pathogens responsible for the necrosis and sloughing of tissue. SRN may be a reversible condition. Antonius (1981b) noted that it was rarely lethal for the whole colony in Diploria strigosa, Montastrea annularis, and $M$. ferox. Gladfelter et al. (1977) noted an occasional reversal of tissue sloughing in Acropora palmata afflicted with WBD, with tissue regrowth. These colonies may not have been infected with the bacteria, or may have recovered from the infection. In all these cases of sloughing tissue, tissue is lost first from the basal edge of the colony. This tissue may be metabolically older, or may be more shaded and less likely to be in a favorable position for zooxanthellar nutrient acquisition. Thus, necrosis and sloughing of the tissue occurs first in this region.

During this study, no visible signs of diseases were found on the shallower reefs of Guayanilla Bay. However, there had been a noticeable loss of living coral cover and erosion of reef structure. Both were dependent on the tolerance of individual colonies, as well as the species, to chronic turbidity and sedimentation (Morelock, 1979). Histopathological examination of the corals at this site revealed signs of stress, including increased mucus-secretory activity and epidermal cell erosion. Only one possible case of bacterial colonization, indicated by a whitish film of Beggiatoa filaments, was seen. Laboratory studies by Ducklow \& Mitchell (1979) and Rublee et al. (1980) indicated that mucus production and surface bacterial populations increased with increasing turbidity or other irritants, leading to the development of anoxic conditions on the surface of the coral, and the appearance of the sulfur-reducing bacterium Desulfovibrio. Finally, heterotrophic sulfide-oxidizing Beggiatoa filaments form a net over the necrotic tissue (Mitchell \& Chet, 1975). Another unusual finding was the presence of amoebae that destroyed the calicoblastic epithelium in four colonies of Siderastrea spp., found only at this site. While skeletal growth may be lower here because the turbidity-reduced light levels are adversely affecting the zooxanthellae-coral calcification system, the protozoans may also interfere with this process. Although weakened by constant heavy mucus production and microparasites, it appears that the corals remaining at Guayanilla Bay are still able to meet their metabolic energy expenditures. All species, except the Acropora palmata, contained developing gonads (although the viability of any planula larvae produced is unknown). Rinkevich \& Loya (1977) and Peters et al. (1981) reported reduced or absence of gonad development in corals exposed to chronic oil pollution, and suggested that other environmental stress conditions might inhibit reproduction in corals.

As found in this study, reefs under chronic sedimentation stress may not be totally 
destroyed (Roy \& Smith, 1971). The presence of young Acropora palmata indicates that recruitment from adjacent reefs may occur. However, Morelock et al. (1979) noted that the substrate here has been covered by algae and sediment accumulations, which reduces the potential settling sites for planulae, and also damages established colonies. The histopathological observations reveal that edge zone coral tissues develop an epidermal cell hyperplasia, probably due to chronic irritation (Cheville, 1976). This is influenced by colony morphology as well as sediment loading. Colonies are constantly sweeping particles which fall on their surfaces to the edge of the tissue, where they may be removed by water currents. If the sediment is not removed, it may become a substrate for algal colonization. Walker \& Ormond (1982) noted that increased algal growth may increase the sediment load experienced by corals, by trapping sediment on enhanced filamentous algal growth. Schumacher (1979) found that the number of functioning mucus cells decreases with increasing sediment load and are not replaced. Eventually, the cells at the colony border may die. Hughes \& Jackson (1980) noted that partial colony mortalities are difficult to detect in situ, unless time-series photographs are examined, because skeleton which appears as a result of the death of coral tissue is readily overgrown by algae. As this phenomenon also affected colonies on the other reefs examined in this study, along with Beggiatoa nets and outbreaks of disease and microparasites, these observations suggest that perhaps localized changes in water quality may also be important in controlling the health of corals on reefs. Furthermore, the interaction of pathogens and microparasites with physical stress and injuries may be as important in regulating natural populations of corals as in other invertebrates (Anderson \& May, 1981), and may also be influenced by species-specific susceptibility to invasion by a pathogen.

For the reefs studied here, it appears that daily and seasonal variations in sedimentation and turbidity are more likely to occur than acute salinity or temperature perturbations. For example, sedimentation rates are increased, on the deeper reefs of the El Negro-Bank (Loya, 1976), by rainy season river inputs of sediments which do not accumulate on the shallower reefs. However, winter storms associated with northwesterly fronts may resuspend these sediments, and may have contributed to the death of A. palmata colonies in 1980 . Corals were actively shedding sediment at the La Parguera patch reef during this study, but high winds and seas, common on summer days along the southern coast of Puerto Rico (Almy \& Carrion-Torres, 1963), are reduced in the winter. The amount and duration of stress experienced by an individual coral colony during these infrequent episodes of sedimentation and turbidity, as well as during intense tropical storms (Endean, 1976; Connell, 1978), will be affected by surrounding irregularities in reef topography and sediment deposits. These habitat variations change with time, and with the growth, death, and erosion of neighboring colonies (Dana, 1976).

The effects of these small-scale microhabit disturbances are easily seen in coralalgal interactions. Besides the development of epidermal cell hyperplasia in response to sediment-algae accumulations along the margins of colonies, a major cause of loss of living coral tissue from the Tague Bay, El Negro and La Parguera reefs was the widespread development of territorial algal lawns by damselfish (Brawley \& Adey, 1977; Kaufman, 1977; Lobel, 1980). These fish continuously remove coral tissue, to provide a bare substrate which is colonized by algae. Normally, tissue may regenerate to cover small lesions very quickly (Bak \& Steward-van Es, 1980). Sammarco \& Williams (1982) 
found that damselfish increased the numbers of rarer corals such as Favia because this species is more resistant to algae. From his studies of Pacific damselfish, Potts (1977) concluded that the algal mat caused corals to expend energy to keep surfaces clean, and death followed the exhaustion of metabolic reserves during periods of minimum nutrient availability.

Fish and other organisms which prey on corals (Robertson, 1970; Ott \& Lewis, 1972; Antonius, 1973; Glynn, 1973; Endean, 1976; Brawley \& Adey, 1982) may be responsible for the spread of some of the diseases and microparasites. In particular, microorganisms caught in the mucus layer of the fishes' mouths could be spread as they feed on coral tissue (D. Spoon, pers. comm.). Gladfelter et al. (1977) and Frydl (1979) noted that parrotfish feed on Porites astreoides, Acropora palmata, Diploria strigosa and Montastrea annularis. All of these species are afflicted by parasites, WBD and BLD.

BLD is rarely encountered (1-2\% incidence) on reefs throughout the Caribbean and off Bermuda (Antonius, 1973; Garrett \& Duckow, 1975). The high incidence of this disease at the reef crest swim channel at Tague Bay may have been due to heavy wave surge sediment resuspension, and natural predators, as well as from coral injuries due to diver traffic, thus supporting observations that environmental stress (Antonius, 1977; Dustan, 1977; Ducklow \& Mitchell, 1979) and tissue injuries (Antonius, 1981b) may increase the occurrence of this disease. WBD was first reported by Gladfelter et al. (1977) from St. Croix reefs well before the hurricane damage, but it appears that physical injuries and stress may also influence this disease. Knowlton et al. (1981) observed that hurricane-damaged $A$. cervicornis off Jamaica that may have been killed by a disease (symptoms of WBD), which they believed may have been present on the reef, and its spread was accelerated by stress. In experiments off Curaçao, Bak \& Criens (1981) fragmented Acorpora spp, and found that despite an initial increase in cover, all fragments came down with a disease in which tissues sloughed off the skeleton three months later. Fragmented colonies of Madracis mirabilis were unaffected. The histopathological observations in this study indicate that the WBD-associated bacterial colonies may be present in corals for some time before signs of the disease are visible. In addition to finding the amoebae in Siderastrea spp. at Guayanilla Bay, the occurrence of the colony of $P$. porites, which was most heavily infested with Nematopsis sp. spores in the Coral Reef Microcosm suggests that environmental stress may likewise affect the infestation of some microparasites. Anderson \& May (1981) noted that occult infections of pathogens or parasites, which can exist in apparently healthy hosts but increase in numbers and cause mortality or decreased reproductive potential when the host organism is stressed, are little understood.

Acknowledgements. I am deeply indebted to P. Yevich, Chief Histopathologist of the Environmental Protection Agency's Environmental Research Laboratory, Narragansett, Rhode Island, for providing support, laboratory facilities, and assistance with the diagnoses during this study. I also thank the staffs of the West Indies Laboratory, St, Croix, and the Center for Energy and Environment Research, Puerto Rico, for facilities and assistance; and especially R, Clark, D. Corvales, J. Gonzalez and $\mathrm{H}$. McCarty for their assistance in the laboratory and diving field work. In addition to those previously mentioned in the manuscript, M. Pilson, N. Marshall, P. Chang, H. McCarty, J. Oprandy, H. Ducklow, W. Gladfelter, C. Yevich, J. Sieburth, S. Brawley, and L. St. Pierre were most helpful with analysis, discussions and/or criticizing the manuscript. Comments from two anonymous reviewers greatly aided the manuscript revision. Special thanks to R. Kelly and R. Kerstetter, Furman University, for the emergency use of a microscope. This research is part of a dissertation 
presented to the University of Rhode Island in partial fulfillment of the requirements for the Doctor of Philosophy degree. It was partially funded by the Lerner Fund for Marine Research of the American Museum of Natural History.

\section{LITERATURE CITED}

Adey, W. H., 1983. The microcosm: a new tool for reef research. - Coral Reefs 1, 193-201.

Almy, C. C., Jr. \& Carrion-Torres, C., 1963. Shallow-water stony corals of Puerto Rico. - Caribb. J. Sci. 3, 133-162.

Anderson, R. M. \& May, R. M., 1981. The population dynamics of microparasites and their invertebrate hosts. - Phil. Trans. R. Soc. Lond. (B) 291, 451-524.

Antonius, A., 1973. New observations on coral destruction in reefs. Meet. Ass. Isl. Mar. Lab. Caribb., Univ. Puerto Rico, Mayaguez, 10, 3 (Abstracts).

Antonius, A., 1977. Coral mortality in reefs: a problem for science and management. - Proc. 3rd int. Coral Reef Symp., Miami, 2,617-623.

Antonius, A., 1981a. Coral reef pathology: a review. - Proc. 4th int. Coral Reef Symp., Manila, 2, $3-6$.

Antonius, A., 1981b. The "band" diseases in coral reefs. - Proc. 4th int. Coral Reef Symp., Manila, 2, 6-14.

Bak, R. P. M., 1978. Lethal and sublethal effects of dredging on reef corals. - Mar. Pollut. Bull. 9 r 14-16.

Bak, R. P. M., 1983. Neoplasia, regeneration and growth in the reef-building coral Acropora palmata. - Mar. Biol. 77, 221-227.

Bak, R. P. M. \& Criens, S. R., 1981. Survival after fragmentation of colonies of Madracis mirabilis, Acropora palmata and A. cervicornis (Scleractinia) and the subsequent impact of a coral disease. - Proc. 4th int. Coral Reef Symp., Manila, 2, 221-228.

Bak, R. P. M. \& Elgershuizen, J. H. B. W., 1976. Patterns of oil-sediment rejection in corals. - Mar. Biol. 37, 105-113.

Bak, R. P. M. \& Steward-van Es, Y., 1980. Regeneration of superficial damage in the scleractinian corals Agaricia agaricites f. purpurea and Porites astreoides. - Bull. mar. Sci. 30, 883-887.

Bang, F. B., 1980. Monitoring pathological changes as they occur in estuaries and in the ocean in order to measure pollution (with special reference to invertebrates), - Rapp. P. -v. Reun. Cons. int. Explor. Mer 179, 118-124.

Barszcz, C. A. \& Yevich, P. P., 1975. The use of Helly's fixative for marine invertebrate histopathology. - Comp. Path. Bull. 7, 4.

Brawley, S. H. \& Adey, W. H., 1977. Territorial behavior of threespot damselfish (Eupomacentrus planifrons) increases reef algal biomass and productivity. - Environ. Biol. Fish. 2, 45-51.

Brawley, S. H. \& Adey, W. H., 1982. Coralliophila abbreviata: a significant corallivore! - Bull. mar. Sci. 32, 595-599.

Burkholder, P. R. \& Burkholder, L. M., 1958. Antimicrobial activity of horny corals. - Science, N. Y. $199,1302-1309$.

Butter, M. E., 1979. Biology and infestation rate of Corallonoxia longicauda, an endoparasitic copepod of the West Indian reef coral Meandrina meandrites. - Bijdr. Dierk. 48, 141-155.

Cheney, D. P., 1975. Hard tissue tumors of scleractinian corals. In: Immunologic phylogeny. Ed. by W. H. Hildemann \& A. A. Benedict. Plenum Press, New York, 77-87.

Cheng, T. C. \& Wong, A. K. L., 1974. Chemical, histochemical and histopathological studies on corals, Porites spp., parasitized by trematode metacercariae. - J. Invertebr. Pathol. 23, 303-317.

Cheville, N. F., 1976. Cell Pathology. The Iowa State Univ. Press, Ames, 515 pp.

Connell, J. H., 1978. Diversity in tropical rain forests and coral reefs. - Science, N. Y. 199, 1302-1309.

Dana, T. F., 1976. Reef-coral dispersion patterns and environmental variables on a Caribbean coral reef. - Bull. mar. Sci. 26, 1-13.

Dodge, R. E., Aller, R. C. \& Thomson, J., 1974. Coral growth related to resuspension of bottom sediments. - Nature, Lond. 247, 574-577. 
Dodge, R. E. \& Vaisnys, J. R., 1977. Coral populations and growth patterns: responses to sedimentation and turbidity associated with dredging. - J. mar. Res. 35, 715-730.

Ducklow, H.W. \& Mitchell, R., 1979. Observations on naturally and artificially diseased tropical corals: a scanning electron microscope study. - Microb. Ecol. 5, 215-233.

Dustan, P., 1977. Vitality of reef coral populations off Key Largo: recruitment and mortality. Environ. Geol. 2, 51-58.

Endean, R., 1976. Destruction and recovery of coral reef communities. In: Biology and geology of coral reefs. Ed. by O. A. Jones \& R. Endean. Acad. Press, New York, 3, 215-254.

Frydl, P., 1979. The effect of parrotfish (Scaridae) on coral in Barbados, W. I. - Int. Revue ges. Hydrobiol. 64, 737-748.

Garrett, P. \& Ducklow, H., 1975. Coral diseases in Bermuda. - Nature, Lond, 253, 349-350.

Gladfelter, W. B., 1982. White band disease in Acropora palmata: implications for the structure and growth of shallow reefs. - Bull. mar. Sci., 32, 639-643.

Gladfelter, W. B., Gladfelter, E. H., Monahan, R. K., Ogden, J. C. \& Dill, R. F., 1977. Coral destruction. Environmental Studies of Buck Island Reef National Monument. - U. S. Natn. Park Service Rep., 144 pp.

Glynn, P. W., 1973. Aspects of the ecology of coral reefs in the Western Atlantic region. In: Biology and geology of coral reefs. Ed. by O. A. Jones \& R. Endean. Acad. Press, New York, 2, 271-325.

Glynn, P. W., Almodovar, L. R. \& Gonzalez, J. G., 1964. Effects of Hurricane Edith on marine life in La Parguera, Puerto Rico. - Caribb. J. Sci. 4, 335-345.

Goreau, T. F., 1964. Mass expulsion of zooxanthellae from Jamaican reef communities after Hurricane Flora. - Science N. Y. 145, 383-386.

Goreau, T. F., Goreau, N. I. \& Goreau, T. J., 1979. Corals and coral reefs, - Scient. Am. 24, $124-136$.

Grigg, R. W. \& Dollar, S. J., 1981. Impact of a kaolin clay spill on a coral reef in Hawaii. - Mar. Biol. $65,269-276$.

Herriott, A. B. \& Immermann, F. W., 1979. A preliminary report on copepods endoparasitic in stony corals of St. Croix, U. S. Virgin Islands. - Crustaceana 36, 166-172.

Hodgins, H. O., McCain, B. B. \& Hawkes, J. W., 1977. Marine fish and invertebrate diseases, host disease resistance, and pathological effects of petroleum. In: Effects of petroleum on arctic and subarctic marine environments and organisms. Ed. by D. C. Malins. Acad. Press, New York, 2, 95-175.

Hubbard, J. A. E. B. \& Pocock, Y.P., 1972. Sediment rejection by recent scleractinian corals: a key to paleoenvironmental reconstruction. - Geol. Rdsch. 61, 598-626.

Hudson, J. H., 1981a. Growth rates of Montastrea annularis: a record of environmental change in Key Largo Reef Marine Sanctuary, Florida. - Bull. mar. Sci. 31, 444-459.

Hudson, J. H., 1981b. Response of Montastrea annularis to environmental change in the Florida Keys. - Proc. 4th int. Coral Reef Symp., Manila, 2, 233-240.

Hughes, T. P. \& Jackson, J. B. C., 1980. Do corals lie about their age? Some demographic consequences of partial mortality, fission, and fusion. - Science, N. Y. 209, 713-715.

Johannes, R. E., 1972. Coral reefs and pollution. In: Marine pollution and sea life. Ed. by M. Ruivo. Fishing News Books, London, 364-375.

Johannes, R. E., 1975. Pollution and degradation of coral reef communities. In: Tropical marine pollution. Ed. by E. G. F. Wood \& R. E. Johannes. Elsevier, New York, 13-51.

Johannes, R. E., 1976. Life and death of the reef. - Audubon 78, 36-55.

Kaufman, L., 1977. The threespot damselfish: effects on benthic biota of Caribbean coral reefs. Proc. 3rd int. Coral Reef Symp., Miami, 1, 559-564.

Knowlton, N., Lang, J. C., Rooney, M. C. \& Clifford, P., 1981. When hurricanes kill corals: evidence for delayed mortality in Jamaican staghorns. - Nature, Lond. 294, 251-252.

Kudo, R. R, 1966. Protozoology. Thomas, Springfield, I1, 1174 pp.

Lauckner, G., 1980. Diseases of Cnidaria. In: Diseases of marine animals. Ed. by O. Kinne. Wiley, New York, 1, 167-237.

Lobel, P. S., 1980. Herbivory by damselfishes and their role in coral reef community ecology. - Bull. mar. Sci. 30, 273-289.

Lopez, J. M. (Ed.), 1979. Proceedings of the Symposium on energy industry and the marine environment in Guayanilla Bay. Univ. Puerto Rico, U. S. Dep. of Energy, 94 pp. 
Loya, Y., 1972. Community structure and species diversity of hermatypic corals at Eilat, Red Sea. Mar. Biol. 13, 100-123.

Loya, Y., 1976. Effects of water turbidity and sedimentation on the community structure of Puerto Rican corals. - Bull. mar. Sci. 26, 450-466.

Loya, Y., 1977. Plotless and transect methods. In: Coral reefs: research methods. Ed. by D. R. Stoddart \& R. E. Johannes. UNESCO, Paris, 197-217.

Lukas, K. J., 1973. Taxonomy and ecology of the endolithic microflora of reef corals with a review of the literature on endolithic microphytes. Ph. D. Thesis, Univ. Rhode Island, $159 \mathrm{pp}$.

Luna, L. G. (Ed.), 1968. Manual of histologic techniques of the Armed Forces Institute of Pathology. McGraw-Hill, New York, $258 \mathrm{pp}$.

Marshall, S. M. \& Orr A. P., 1931. Sedimentation on Low Isles Reef and its relation to coral growth.Scient. Rep. Gt. Barrier Reef Exped. 1 (5), 94-133.

Marszalek, D. S., 1981. Impact of dredging on a subtropical reef community, southeast Florida, U. S. A. - Proc. 4th int. Coral Reef Symp., Manila 1, 147-153.

Mitchell, R. \& Chet, I., 1975. Bacterial attack of corals in polluted seawater. - Microb. Ecol. 2, $227-233$.

Morelock, J., Boulon, K. \& Galler, G., 1979. Sediment stress and coral reefs. In: Proceedings of the Symposium on energy industry and the marine environment in Guayanilla Bay. Univ. Puerto Rico, U. S. Dep. of Energy, 46-58.

Morelock, J., Schniedermann, N. \& Bryant, W. R., 1977. Shelf reefs, southwestern Puerto Rico. In: Reefs and related carbonates - ecology and sedimentology. Am. Ass. Petr. Geol., Tulsa, 135-153.

Muscatine, L., 1973. Nutrition of corals. In: Biology and geology of coral reefs. Ed. by O. A. Jones \& R. Endean. Acad. Press, New York, 2, 77-115.

Odum, H. T. \& Odum, E. P., 1955. Trophic structure and productivity of a windward coral reef community on Eniwetok Atoll. - Ecol. Monogr. 25, 291-320.

Ott, B. \& Lewis, J. B., 1972. The importance of the gastropod Coralliophila abbreviata (Lamarck) and the polychaete Hermodice carunculata (Pallas) as coral reef predators. - Can. J. Zool., 50, 1651-1656.

Peters, E. C., 1978. Effects of long-term exposure of the coral Manicina areolata (Linné, 1758) to water-soluble oil extracts. M. S. Thesis, Univ. South Florida, Tampa, $167 \mathrm{pp}$.

Peters, E. C., Meyers, P. A., Yevich, P. P. \& Blake, N. J., 1981. Bioaccumulation and histopathological effects of oil on a stony coral. - Mar. Pollut. Bull. 12, 333-339.

Peters, E. C., Oprandy, J. J. \& Yevich, P. P., 1983. Possible causal agent of "white band disease" in Caribbean acroporid corals. - J. Invertebr. Pathol. 41, 394-396.

Potts, D. C., 1977. Suppression of coral populations by filamentous algae within damselfish territories, - J. exp. mar. Biol. Ecol. 28, 207-216.

Ricard, M., 1981. Some effects of dredging on the primary production of the Tiahura Lagoon in Moorea (Society Islands, French Polynesia). - Proc, 4th int. Coral Reef Symp., Manila, 1, $431-436$.

Rinkevich, B. \& Loya, Y., 1977. Harmful effects of chronic oil pollution on a Red Sea scleractinian coral population. - Proc. 3rd int. Coral Reef Symp., Miami, 2, 585-591.

Rinkevich, B. \& Loya, Y., 1979. Laboratory experiments on the effects of crude oil on the Red Sea coral Stylophora pistillata. - Mar. Pollut. Bull. 10, 328-330.

Robertson, R., 1970. Review of the predators and parasites of stony corals, with special reference to symbiotic prosobranch gastropods. - Pacif. Sci. 24, 43-54.

Rogers, C. S., 1977. The response of a coral reef to sedimentation. Ph. D. Thesis, Univ. Florida, Gainesville, $195 \mathrm{pp}$.

Rogers, C. S., 1979. The effect of shading on coral reef structure and function. - J, exp. mar. Biol. Ecol. 41, 269-288.

Rogers, C. S., Suchanek, T. H. \& Pecora, F. A., 1982. Effects of hurricanes David and Frederic (1979) on shallow Acropora palmata reef communities: St. Croix, U. S. Virgin Islands. - Bull. mar. Sci. $32,532-548$.

Roy, K. J. \& Smith, S. V., 1971. Sedimentation and coral reef development in turbid water: Fanning Lagoon. - Pacif. Sci. 25, 234-248.

Rublee, P. A., Lasker, H. R., Gottfried, M. \& Roman, M. R., 1980. Production and bacterial colonization of mucus from the soft coral Briareum asbestinum. - Bull. mar. Sci. 30, 888-893. 
Sammarco, P. W. \& Williams, A. H., 1982. Damselfish territoriality: influence on Diadema distribution and implications for coral community structure. - Mar. Ecol. Prog. Ser. 8, 53-59.

Schumacher, H., 1979. Experimentelle Untersuchungen zur Anpassung von Fungiiden (Scleractinia, Fungiidae) an unterschiedliche Sedimentations- und Bodenverhältnisse. - Int. Rev. ges. Hydrobiol. 64, 207-318.

Sheppard, C. R. C., 1980. Coral fauna of Diego Garcia lagoon, following harbour construction. Mar. Pollut. Bull. 11, 227-230.

Sheppard, C. R. C., 1982. Coral populations on reef slopes and their major controls. - Mar. Ecol. Prog. Ser. 7, 83-115.

Sindermann, C. J., Bang, F. B., Christensen, N. O., Dethlefsen, V., Harshbarger, J. C., Mitchell, J. R. \& Mulcahy, M. F., 1980. The role and value of pathobiology in pollution effects monitoring programs. - Rapp. P. -v. Reun. Cons. int. Explor. Mer 179, 135-151.

Squires, D. F, 1962. Corals at the mouth of the Rewa River, Viti Levu, Fiji. - Nature, Lond. 195, $361-362$.

Stebbing, A. R. D., 1981. Stress, health and homeostasis, - Mar. Pollut. Bull. 12, 326-329.

Stephenson, W., Endean, R. \& Bennett, I., 1958. An ecological survey of the marine fauna of Low Isles, Queensland. - Aust. J. mar. Freshwat. Res. 9, 261-318.

Stock, J. H., 1975. Corallovexiidae, a new family of transformed copepods endoparasitic in reef corals. - Stud. Fauna Curaçao 155, 1-45.

Voss, G. L., 1973. Sickness and death in Florida's coral reefs. - Nat. Hist. 82, 41-47.

Walker, D. I. \& Ormond, R. F. G., 1982. Coral death from sewage and phosphate pollution at Aquaba, Red Sea. - Mar. Pollut. Bull. 13, 21-25.

Yevich, P. P. \& Barszcz, C. A., 1982. Preparation of aquatic animals for histopathological examination. In: Biological field and laboratory methods for measuring the quality of surface waters and effluents. U. S. Environ. Prot. Agency, Cinncinati, Ohio. (In press).

Yevich, P. P. \& Barszcz, C. A., 1983. Histopathology as a monitor for marine pollution: results of the histopathologic examination of the animals collected for the U. S. 1976 Mussel Watch Program. Rapp. P. -v. Reun. Cons, int. Explor. Mer 182, 96-102. 